\title{
UNIVERSITYOF
}

FORWARD

THINKING

WESTMINSTER用

WestminsterResearch

http://www.westminster.ac.uk/westminsterresearch

Travelling with golf clubs: the influence of baggage on the trip decision-making process

Humphreys, C.

This is an accepted manuscript of an article published by Taylor \& Francis in the Journal of Sport \& Tourism, doi: 10.1080/14775085.2016.1249017. Published online: 03 Nov 2016. The final definitive version is available online:

https://dx.doi.org/10.1080/14775085.2016.1249017

(c) Taylor \& Francis Inc.

The WestminsterResearch online digital archive at the University of Westminster aims to make the research output of the University available to a wider audience. Copyright and Moral Rights remain with the authors and/or copyright owners.

Whilst further distribution of specific materials from within this archive is forbidden, you may freely distribute the URL of WestminsterResearch: ((http://westminsterresearch.wmin.ac.uk/)).

In case of abuse or copyright appearing without permission e-mail repository@westminster.ac.uk 
Dr Claire Humphreys

Principal Lecturer in Tourism and Events

University of Westminster, 35 Marylebone Road, London, NW1 5LS

+442079115000

c.j.humphreys@westminster.ac.uk

\section{Travelling with golf clubs: the influence of baggage on the trip decision-making process}

\section{ABSTRACT}

Sports participation often requires the use of specialist equipment and for many sport tourists this is transported to the destination to aid convenience and enjoyment of participation. Yet, to date there has been little consideration of the influence that travelling with sporting equipment can have on the trip decisions making process. This paper focuses on golf tourism, said to be the largest sector of the sports tourism market and examines the influence that traveling with golf equipment has on aspects of the trip such as travel mode and opportunities for participation.

Based on a longitudinal grounded theory study this paper concludes that packing sporting equipment can stimulate negotiations associated with participation. Furthermore the nature of the sporting equipment to be carried can determine the choices made regarding the travel modes used to reach and move around holiday destinations and thus directly influence the trip decision making process.

KEYWORDS

Golf tourism, decision making, negotiation, baggage, sporting equipment, grounded theory 


\section{Introduction}

Golf tourism, globally worth $\$ 20$ billion (Hudson and Hudson, 2014) is a significant sector of the sports tourism industry. Around seven percent of the UK population play golf at least once a year (Mintel, 2014) although only around one quarter of this number are regular participants, playing at least once a week (Sport England, 2014). Despite this lack of regular involvement around three percent of the UK population take golf holidays annually (Mintel, 2015). To attract international visitors numerous golf tourism strategies have been developed by regional and national tourism organisations (Tourism New Zealand, 2013, Australian Golf Industry Council, 2014, Scottish Golf Tourism, 2013, Tourism Northern Ireland, 2015) while academic research has explored its importance for destinations (Jorge and Monteiro, 2011, Completo and Gustavo, 2014, Butler, 2005, Markwick, 2000) and many aspects of golf tourism behaviours (Tassiopoulos and Haydam, 2008, Petrick and Backman, 2002, Hutchinson et al., 2009, Humphreys and Weed, 2012, Geissler, 2005).

Although this has included exploration of tourist decision making, to date there is little research related to the effect that the transportation of sporting equipment has on the trip decision making process. Travelling with sporting equipment is being influenced by structural changes. Charges for the transportation of sporting equipment has been introduced by many airlines while increased ownership of sporting equipment and increased sports tourism participation have shaped demand. Furthermore there is a paucity of literature related to baggage as an influential factor on choices of tourism transport modes, with most research focusing on travel economics and the utilitarian needs of travel mode decisions such as cost and speed (Gross and Klemmer, 2014). The multi-modal elements of tourism transport (getting from home to the destination - often via major transport hubs or ports - as well as moving around the destination) requires many interchanges which can be challenging if extensive baggage, including sporting equipment is transported. Thus this paper extends insight into the trip decisions associated with the transportation of sporting equipment by holidaymakers. 


\section{Understanding trip decision making}

The decision making process underlying leisure trips has received significant attention in literature (Um and Crompton, 1990, Decrop and Snelders, 2005, Gilbert, 1991) with foundational models assuming a functional process influenced by psychological and nonpsychological variables (Sirakaya and Woodside, 2005). Although some early work assumed the traveller to be a rational decision maker (Wahab et al., 1976, Schmoll, 1977), this is countered in more recent research arguing that frequently heuristic techniques influence choices made (McCabe et al., 2015) and that utility maximisation is not always sought (Woodside and MacDonald, 1994) as personal characteristics (such as aspirations and motivations) interact with household factors (such as family structure, lifestage, power dynamics and life style) to influence decisions (Woodside and Lysonski, 1989, Decrop and Snelders, 2005, van Raaij and Francken, 1984). While behavioural economics acknowledges that heuristics save effort in decision making at the cost of accurate, calculated, rational decisions, it asserts that "decisions are not always optimal" (Samson, 2014:2), with irrationality, inertia and social dimensions such as trust and commitment influencing behaviour.

Trip decision making models historically assumed a process of sequential steps which included (1) recognition of the vacation need, (2) information search, (3) appraisal of alternatives, (4) purchase and (5) post-purchase evaluation. Such approaches focused on the features assessed to select a holiday destination rather than appreciating the complex decisions made to assess the many interrelated component parts (Choi et al., 2011). Decision making theorists now acknowledge the dynamic and multi-stage processes which determine travel planning, whereby "decisions made later in the process are contingent upon those made earlier" (Hwang et al., 2006, 21), with some proposing a hierarchy of decisions related to component parts of the trip. Decrop (2006) postulates that generic decisions regarding whether to take a trip will supersede decisions on the type of trip and destination, transport and accommodation choices. Motivations to travel can energise travellers to make the generic decision to take a trip while demand is constrained by factors such as income and life stage. Thus although purchasing behaviour may be stimulated by 
numerous motivations, such as the desire to escape routine, this is filtered by numerous demographic and socio-economic factors which constrain choices (Gilbert, 1991).

Many trip decision making models focus on the individual, despite the vast majority of travel being with other people (Stone, 2016). Despite Gilbert's assertion more than a quarter of a century ago that the family as an, at times incongruent, buying unit rather than the individual should shape understanding of the trip decision making process, there is still limited attention is given to the influence of multiple travel participants. Furthermore Swarbrooke and Horner (1999:56) assert that 'most people's holidays represent a compromise between their multiple motivators. Either one motivation becomes dominant or a holiday is purchased which ensures all the motivators can at least be partly satisfied'. Thus many motivations will inform trip decision making and that trips are determined not by a single decision but through a process which accounts for the many different motives of the individual and frequently an associated decision making unit (DMU) (Decrop and Snelders, 2005). While the DMU may comprise of the individual, family or friends taking the trip, an extended DMU, comprising family members who may not be taking the trip, will also influence trip decision, with negotiation and compromise inevitable as a result. Moreover while many decision making models assume the individual as decision maker, Stone (2016) asserted that a significant number of travellers delegate decisions to others in the travel party. Zhang et al (2009) suggest that both individual and household utility (the benefits expected to be achieved) are considered in the decision making process, although this is a subjective assessment of expected utility (Decrop, 2006) in that 'most human decisions are not perfectly rational' (Sirakaya and Woodside, 2005: 816). This means that decisions take into account the views of the extended DMU. The need to consider other family members, particularly children, leads to a complex decision making process, with negotiations frequently considering not just a single trip but the wider schedule of trips, often spanning many months, expected to be taken by different members of the extended DMU (Humphreys and Weed, 2012).

While the decision making literature discussed above has focused on behaviours (rational or otherwise) of decision makers, a choice-set approach has received attention for its practical 
application (Um and Crompton, 1990, Crompton, 1992). Such an approach proposes that travellers are aware of a set of destinations from which is eliminated those judged less acceptable based on information garnered (from media, past experience, friends and family), motivational needs and situational constraints. Furthermore choices for different elements (destination, accommodation, travel companions, mode of travel, trip timing and duration of the trip) are interrelated (Dellaert et al., 1998). While all elements impact the choice set, this paper gives particular attention to transport mode, a 'critical element in holiday decision making' (Hergesell and Dickinger, 2013: 596). Transport modes (road, rail, air and sea) are generally determined by their speed, capacity, comfort, cost and safety (Prideaux, 2000). Furthermore Mill and Morrison (2012) argue that situational and functional utility impact choice of travel mode. This is often considered in terms of cost, comfort and convenience. In modelling transport choices Ortuzar and Willumsen (2011) propose that the characteristics of the trip maker, the journey itself and the transport facility determine selection. However they offer little direct consideration of the ability to transport travel baggage, particularly if this is cumbersome or heavy, despite the appreciation that managing such baggage seen as a situational influence on mode choices for rail and air travel (Last and Manz, 2003, Gosling, 2008). Instead baggage handling is largely considered under the broad heading of 'convenience' (Sheldon and Mak, 1987).

The equipment for some sports participation (for example swimming and running) is usually both small and light to transport, thus decision-making related to transporting such equipment is often swiftly made. However several sports require equipment which can be bulky, unwieldy or fragile, leading to greater debate as to whether they should be included in holiday baggage. For those whose journey includes an element of public transport, again the nature and weight of baggage can influence travel mode choice. Thus baggage can be a perceived barrier for some transport modes and impact decision making (Anable, 2006).

Furthermore while it is often possible to borrow or hire equipment many sports tourists, especially those participating frequently or at an elite level often elect to purchase their own equipment. In some cases this equipment has been fitted to directly suit the individual. Therefore when deciding to take a trip which includes participating in particular 
sporting activity a further decision must be made regarding whether to take equipment as part of the traveller's baggage.

\subsection{Travelling with sports tourism equipment}

Early work exploring sports tourism (Gammon and Robinson, 1997) recognised the interrelationship between sport and tourism motives, refining discussions to assert the existence of dominant, primary motives driven by either sport or tourism desires and underlying, secondary motives offering enrichment to the experience (Robinson and Gammon, 2004). However, a focus on either sport or tourism is an over-simplification which ignores the diversity of motives which underpin the decision making process because the sports tourism element is but one part of the overall trip (Weed and Bull, 2012). Therefore the decision-making process in relation to travelling with sporting equipment is determined only in part by the extent to which the sporting activity is seen as a dominant activity. In cases where participation is high (frequency of participation and/or expected level of skilled performance) the utility received by transporting owned equipment rather than using rental gear is likely to be high. However trips where the sporting activity is not expected to be a dominant activity - and may form only one among several activities to be undertaken during the trip - can mean that the utility achieved by having access to personalised sporting equipment is offset against the inconvenience of having to transport and store these items when not in use. Furthermore some forms of a sport may be less 'equipment-intensive' and compromises are accepted in terms of performance and experience levels (Breivik, 2011: 323).

Travelling with sports equipment can have a direct cost. Those selecting air as a travel mode to reach the destination appreciate that while a variety of sporting equipment (archery equipment, bicycles, bowling balls, cricket equipment, fishing tackle, golf clubs, hang gliders, hockey sticks, kayaks, parachutes, paragliders, scuba diving equipment, sporting firearms, skis, water skis, boogie boards, tennis rackets, wind/kitesurfing equipment) is accepted by airlines, a direct charge is levied to transport such items (Skyscanner, 2014, Ustel, 2014). Rail travel normally allows sporting equipment to be 
transported freely as part of a standard baggage allowance, although specialist carry bags may be needed for items such as bicycles. For those travelling by road, transporting equipment may need specialist car racks or larger vehicles, both of which may increase fuel costs.

While travelling with sporting equipment may influence the travel mode used to reach the destination it also influences the convenience of travelling to and from access ports, as well as travelling around the destination. The need for larger taxis or hire cars (or the need for a roof rack or other specialist equipment rack) will further add to the cost of the trip. Therefore decision making in relation to travel mode at the destination will be influenced by such additional costs.

Although travelling with sporting equipment can be difficult, especially if the equipment is cumbersome, it may well add an element of convenience. Skiers arriving in resort with their own equipment can head straight to the slopes without the need to be fitted for equipment at a ski rental shop; cyclists can use the equipment as transport to accommodation or attractions; surfers with their own boards can head straight from the port to the waves. While hiring equipment may provide access to the latest models it may alternatively mean well-used or limited variety is available. Therefore travelling with sporting equipment can guarantee availability of equipment of a suitable type for the skill level of the participant, particularly helpful for the sportsperson who can thus predict equipment performance.

Vacation decision making is a complex and multi-faceted affair which incorporates opinion on the travel modes used to reach and move around destinations (Hyde, 2004). Furthermore, travelling with sporting equipment can also be influenced by the symbolic associations that equipment has to sports participation. Constraints to sports participation can be interpersonal, intra-personal and structural. The intra-personal aspects can include negotiating time to participate, with levels of motivation helping to overcome such constraints, McGuiggan (2004) suggests interpersonal (sufficient motivation) and intrapersonal constraints (the influence of other people) as well as structural issues (access 
logistics) determine participation while constraints on leisure participation put strain on time, money and personal relationship (Lamont et al., 2014). Non-participation can occur when the perceived constraints are not overcome, with intrapersonal constraints of time, money or personal relationships being the least likely to be negotiated (Boo et al., 2014).

Within sport participation literature discussion of the resentment and conflict within family groups is raised, often contextualised in terms of serious leisure participation and marital relationships (Young et al., 2015, Goff et al., 1997, Orthner and Mancini, 1990). It is within this context that travelling with sport equipment can bring symbolic associations linked to expectations of participation. Everyday objects can express meaning of an individual's interests and traits to others, thus represents an individual's relationship to their physical and social space (Csikszentmihalyi and Halton, 1981). Understanding the connection between an object and the individual reveals expressions of self-identity and interest (Fournier, 1991), representing aspects of life deemed to have importance. Furthermore the decision to travel with sports equipment may be a reflection of the identity an individual holds with the sport. Donnelly and Young (2005) conclude that deliberate displays of equipment are a key stage in identity construction for novices seeking affinity with others in their sporting world. Csikszentmihalyi and Halton (1981) also recognise that objects possess both instrumental and symbolic value, thus sporting equipment may deliver a symbolic function to the extent that it provides opportunity for self-expression (Bloch et al., 1989). Thus the symbolic representation of sporting equipment as objects of something held dear, means that the act of transporting sporting equipment can denote an expectation of some level of engagement with a much loved sport- which may be resented by others in the travel group.

Within this paper these inter-related aspects of traveling with sporting equipment is examined though a focus on golf tourism. For golf tourism, trip decision making involves an evaluation of alternatives as a process of making the choice of destinations and activities to be included in the trip (Correia and Pintassilgo, 2006). Furthermore, the demands it places on time, money and family conflict is considered in relationship to the decision to travel with golfing equipment.

\section{Methodology}


This paper draws on data gathered as part of a longitudinal grounded theory study into golf tourism behaviours and presents one aspect of the behaviours revealed. Grounded theory provides a robust methodology (Urquhart, 2013, Strauss and Corbin, 1990, Charmaz and Bryant, 2011) which draws on the principle that theory should emerge from the data gathered with an outcome that it is appropriate and suited to its uses because it is grounded in the data that created it. Although debate of the philosophical perspectives of grounded theory (Charmaz, 2006, Reed and Runquist, 2007, Starks and Brown Trinidad, 2007) as well as divergent opinions on its application exist (Glaser, 1999, Strauss and Corbin, 1994) this has not limited its use in examining disciplines including sport and tourism (Daengbuppha et al., 2006).

Grounded theory employs a process of concurrent data collection and comparative analysis (Charmaz and Bryant, 2011) including the exploration of literature to provide theoretical sensitivity (Glaser and Holton, 2007). This process of constant comparison ensures that as the data is constructed so it is evaluated to identify properties and categories. Analysis of these categories directs the iterations of data collection and analysis until theoretical saturation is reached (Charmaz, 2006). Grounded theory analysis commences with coding to establish initial categories which represent the data (Miles and Huberman, 1994) and as more data is assessed so the categories are evaluated to develop concepts which build into substantive theory (Bringer et al., 2006).

This research employed three iterations which comprised a total of 26 interviews with 24 participants (table 1) alongside examination of literature. Two participants were interviewed at the start and the end of the research process, with this 'member checking' enabling scrutiny of the concepts developed as theory as well as adding transparency to the analytical process (Harry et al., 2005). As each iteration (with 9, 10 and 7 interviews in each cycle) was completed so the data was evaluated and the insights used to inform subsequent iterations, until theoretical saturation was seen to be reached. Golfing frequency as well as the number of golf trips was recorded, helpful in confirming that those interviewed have a golf oriented habitus. Using in-depth qualitative interviews allows complex issues be examined in a way which explains the phenomena in context. Participants were identified 
using a snowball technique (van Meter, 1990), developed from an initial email database of 107 sports participants based in London. Respondents were eligible for interview if they had taken at least one golf holiday in the previous year. This was to ensure that in interview the respondent could draw on experience of actual trips, rather than notional averages of their previous trips or hypothetical ideals.

Table 1: Research Participant Details

\begin{tabular}{|c|c|c|c|c|c|c|}
\hline $\begin{array}{l}\text { Name } \\
\text { (research phase) }\end{array}$ & Gender & Handicap & $\begin{array}{l}\text { Age } \\
\text { Band }\end{array}$ & $\begin{array}{l}\text { Number of } \\
\text { rounds } \\
\text { played } \\
\text { annually }\end{array}$ & $\begin{array}{l}\text { Number of } \\
\text { trips with a } \\
\text { golf tourism } \\
\text { element* }\end{array}$ & $\begin{array}{lr}\text { Total nights } \\
\text { away on } \\
\text { with } \\
\text { tourism } \\
\text { element* } \\
\end{array}$ \\
\hline Alexander (2) & $\mathrm{M}$ & 12 & $55-64$ & 88 & 4 & 11 \\
\hline Alana (2) & $F$ & 33 & $25-34$ & 35 & 2 & 9 \\
\hline Adam (2) & $M$ & 6 & $35-44$ & 44 & 1 & 2 \\
\hline Carter (3) & $\mathrm{M}$ & 11 & $55-64$ & N/A & 2 & 10 \\
\hline Charles (1) & $M$ & 5 & $25-34$ & 38 & 3 & 8 \\
\hline Daisy-Mae (3) & $\mathrm{F}$ & 11 & $35-44$ & 60 & 3 & 10 \\
\hline Debbie (1 \& 3) & $\mathrm{F}$ & 11 & $55-64$ & 28 & 2 & 15 \\
\hline Donald (3) & $M$ & 19 & $55-64$ & 90 & 1 & 15 \\
\hline Eileen (2) & $\mathrm{F}$ & 22 & $55-64$ & 97 & 4 & 24 \\
\hline Gail (2) & $\mathrm{F}$ & 19 & $55-64$ & 97 & 6 & 15 \\
\hline Harley (2) & $M$ & 15 & $25-34$ & 46 & 1 & 3 \\
\hline Ivan (3) & $M$ & 18 & $45-54$ & 46 & 3 & 9 \\
\hline Jeremy (1) & $M$ & 17 & $25-34$ & 28 & 1 & $\mathrm{n} / \mathrm{a}$ \\
\hline Kenneth (2) & $M$ & 15 & $55-64$ & 158 & 8 & 16 \\
\hline Margaret (1) & $F$ & 19 & $65-74$ & 168 & 1 & 6 \\
\hline $\operatorname{Mac}(2)$ & $M$ & 2 & $25-34$ & 52 & 2 & 7 \\
\hline Nathan (2) & $M$ & 14 & $45-54$ & 8 & 1 & 3 \\
\hline Pamela (1) & $F$ & 33 & $45-54$ & 46 & 2 & 15 \\
\hline Rita (3) & $\mathrm{F}$ & 29 & $55-64$ & 55 & 2 & 40 \\
\hline Ryan (1) & $\mathrm{M}$ & 14 & $35-44$ & 12 & 3 & 12 \\
\hline $\operatorname{Rex}(1)$ & $\mathrm{M}$ & 24 & $65-74$ & 48 & 1 & 5 \\
\hline Ray (2) & $M$ & 13 & $45-54$ & 36 & 2 & 6 \\
\hline Steven (1 \& 3) & $M$ & 25 & $25-34$ & 14 & 2 & 8 \\
\hline Tommy (2) & $M$ & 28 & $55-64$ & 35 & 1 & 1 \\
\hline
\end{tabular}

*based on 12 month period prior to interview 
Interviews lasted between 40 minutes and 90 minutes and were directed by an outline topic guide. This ensured some control of the interview while facilitating the emergence of important additional perspectives. All interviews were recorded and transcribed. Although written transcription limits inclusion of non-verbal elements or inflections (Silverman, 2001) the recording was repeatedly revisited to ensure the data analysis retained contextual appreciation.

Thematic analysis (Boyatzis, 1998) using an 'incident by incident' approach to coding (Glaser, 2008) identified in excess of 100 initial codes. These were analysed, detailing their characteristics and relationships to allow the identification of higher-order conceptual ideas to emerge. The process of constant comparisons between the data, literature and categories, informed the development of several higher order and theoretically robust theories related to golf tourist behaviours, one of which - travelling with golfing equipment - informs the findings of this paper.

\section{Discussion - Travelling with golf equipment}

For players taking a golf trip, where the express purpose is to participate in golf, travelling with clubs is expected. However, where golf is not the primary but one possible activity among many then this does not immediately rule out the possibility of traveling with sporting equipment.

'A typical kind to us is to just book a holiday and take our golf clubs with us and look around and if we see a nice course then we book to play it.' (DEBBIE)

When travellers play golf in their home environment it is not surprising that golf may be included in part of their travels, even if this is not the primary motive.

'I suppose because golf is such a big part of my life I do try and combine the two. If I go somewhere to play golf I will try and combine it with seeing friends and things but if I am just going on holiday it won't be as much of an issue to be playing golf.' (MAC) 
Hyde (2004) comments that evolving itineraries can offer serendipitous opportunities to participate and scheduling golf into a holiday may occur as the trip progresses, rather than being planned from the outset and having equipment available can make this more convenient.

The benefit of travelling with golf equipment is frequently assessed in terms the cost of transporting equipment when compared to the cost of hire. This is also balanced in terms of convenience of travel with equipment contrasted with the inconvenience of using hire equipment. ALEXANDER considered his decision not to travel with clubs when visiting family in Australia:

'Well I didn't know I was really going to [play], well yes I suppose [my sonin-law] did say about getting on a course. But [the trip] was six weeks and we were only going to play at the most twice and it is a real pain lumping golf bags around and it costs now quite a lot to, for each leg, it is £15 or $£ 20$ to be able to take a golf bag, so you have got to get your money's worth on that.

The cost of shipping is frequently considered in terms of air travel baggage charges and the tourism industry has seen growing use of baggage companies (such as Luggage Mule, Luggage Forward, Fetch My and Send my Bag) offering golf equipment transportation to hotels and golf courses so that travellers do not incur airline charges. Despite shipping costs, the appeal of using owned equipment often overrides this.

'Now the consideration will be if people like BA charge 160 for your golf clubs - you have to think about whether you want to take your golf clubs. So this year we investigated how much it would cost to hire in Florida and actually it breaks down quite well. Easier to hire your clubs maybe than take out a set so that would a consideration as well now.' (EILEEN)

However despite cost and convenience being a concern when asked about the experience of hiring golf equipment EILEEN replied: 
'We didn't hire, we took [OUR OWN CLUBS] this year. I mean I do prefer to have my own clubs. I think you become familiar with them. I have been to places where I have hired clubs before and they are a little bit peculiar - they are not always a matching set or the loft is different to what you are used to, and the grips are different. - you are used to your own grips when you are doing things, and that makes a difference.'

Amateur golfers, often concerned with performance levels have a strong desire to invest in "a better set of golf clubs"(Stebbins, 1977: 599) thus many own their equipment with which they are familiar. Ownership of golf equipment by players, as well as the acceptance of travelling with golf equipment does mean that many golf clubs often stock only a limited range of equipment for hire. When rental is not common the equipment available may comprise of an incomplete or mismatched set gathered together from multiple original sets as individual clubs are broken or mislaid. Equipment is frequently many years old and the quality and variety available for hire may be especially poor for ladies and left-handed players, which form a smaller market. To address issues of poor quality club hire at golf courses, companies now exist to supply quality, modern sets of rental clubs to tourists visiting popular golf destinations such as Scotland, the Algarve and Las Vegas (Van Sickle, 2016). However, many players still prefer their own set of golf clubs for its familiar performance. Equipment performance is often considered in terms of the physical and technical characteristics, yet Roberts et al (2001) assert that a psychological influence exists, determined by the player's confidence and perception of comfort and fit. Furthermore better players are believed to be more sensitive to the variances in equipment characteristics.

Convenience is also considered in terms of travelling to and from ports. Decisions on travelling with golf equipment can be interrelated to the decisions made regarding mode of transport. Travelling by air is likely to also involve some form of road or rail travel. This influences perception of convenience.

'The only thing for me is understanding who you would be flying with, where you could fly from, because if you are having to face getting from southern London to Stansted, you're flying with Easyjet, Ryanair, of that 
ilk, and having to pay for your golf clubs to go on. And then, you know, having a decent length journey the other end 'cos you're going to have a bag of clothes and things you take anyway, and then you have got your golf clubs on top and it's not as straightforward, it's a bit more bulky, so those little things can be quite critical.' (JEREMY)

'I think I have gone off flying a little bit - it is a bit of hassle dragging your golf clubs to an airport and putting them on the belt and all that sort of stuff. You know hiring cars the other end, is a bit of hassle.' (STEVEN)

The travel interchanges in reaching a destination can thus determine whether golf equipment is taken, but can also shape the elimination process from the destination choice set (Crompton and Ankomah, 1993). Furthermore once at a destination travelling with equipment may be considered in terms of convenience. Some resort golf clubs will provide storage for those golf tourists staying on site, which can reduce the need to transport clubs to the course.

'I do like courses that you can just leave your stuff. I just don't like hassle when I am away so if you can just go to the club and you leave your clubs there at the golf course, leave your clubs there turn up the next day. It is just a nicety that a lot of places do have that.' (ALANA)

Therefore the decision to travel with golf clubs may be determined by the travel mode used to reach and move around the destination. Conversely the destination choice may be included by the convenience it offers to those who have decided to travel with equipment.

While transporting sporting equipment may provide an element of convenience it can also carry connotations about expected behaviours while on a trip. A consequence of this is that is acts as a signifier of intentions, explicit to the travel group that the sporting activity is being considered as one activity which may be undertaken during the trip. If time spent playing the sport is resented by some within the travel group then discussions of transporting equipment is synonymous with discussions of future participation. 
'Now negotiations might be a bit trickier because I am going out to see perhaps joint friends and for me to disappear, it wouldn't go down too well, I shouldn't imagine. We have had that situation, friends of the family that live in Devon I have tried to get a game of golf down there. There was a time when we were going down with my brother-in-law, my sisterin-law, my wife, and I said do you mind if we bring our clubs so leave you and sister with your mum and dad and we can go and play golf. It was absolutely no. No way you can do that.' (HARLEY)

While it may be the sport which is resented there is also an element about engagement with others in the travel group. Participation of multiple family members can enhance family cohesion (Orthner and Mancini, 1990) while those who don't participate may feel a sense of exclusion. Thus the existence of a potential to participate together can strongly influence negotiations regarding golf participation on vacation. For example TOMMY noted that he negotiated the time to play golf when on a Spanish holiday:

'No problem at all, because I was taking the kids. As long as I had the children with me, or the other times that we have played there has been more than one family, so I am not leaving her on her own, she is surrounded by the rest of the family anyway'

Conversely RAY noted that travels with his wife, who does not play golf ruled out participation'

'We went to Spain this year for two weeks and I didn't take the clubs.

Deliberately because I didn't want to play golf while I was off with the family. I need to keep the two separate, I think, for my own conscience.'

Therefore resentment to participation may be ameliorated by the perception others in the travel group hold regarding opportunities lost or gained as a result.

Taking golf equipment may signify the intention to participate and much of the discussion above has noted that travelling with golf clubs can be cumbersome. However, while it is 
possible to hire golf clubs the sport requires additional equipment (specialist shoes, golf balls, gloves and tees) which are not available for hire and are far less bulky to transport. Therefore potential participation may be subtly signified by the transportation of these small items.

'I took a few balls and some tees and my glove. I packed them in case we might play, if I could persuade somebody to go.' (TOMMY)

Such actions can reflect that while there is a desire to participate multiple constraints exist which also must be addressed. Travelling with equipment can ameliorate one perceived constraint but this may bring to the fore the negotiation process with family to spend money and time to achieve participation. This negotiation is overt when golf clubs are carried as baggage but may be less overt (and therefore may not take place until at the holiday destination), when smaller items of equipment are included subtly in travel baggage. Approaches to negotiating the time and money to participate in sports activities is determined by the nature of familial relationships (Barrell et al., 1989) with negotiations determining potential participation levels. Negotiation over time to accommodate the needs of other family members features across literature on decision-making within the family context (Thornton et al., 1997, Zhang et al., 2009, Davis, 1976) and for golf tourism specifically reveals the tacit agreements which involve compensatory activities, some of which may involve extended family and friends (Humphreys and Weed, 2012).

\section{Summary}

When golf is the primary motive for travel then a set of golf clubs will be carried. However, in many cases where golf is not the dominant motive, travel with sports equipment is not ruled out. Therefore if traveling with sporting equipment is being considered this is likely to have an impact on selection of transport mode which can ultimately influence the choice of destination selected. For holidays where golf is not the dominate motive then once a trip is determined and a destination selected travelling with clubs is likely to be evaluated as an option, particularly taking into account transport mode and travel convenience. Furthermore transport choices are shaped not just by functional utility but by the utility of 
multiple travel decisions determined by the entire trip agenda (Recker et al., 1986) and not assessed as single independent choices (Dellaert et al., 1998).

Addressing perceived inconveniences to travelling with sporting equipment may be challenging to overcome both at the destination and in the journey itself. Whether travel is by air, rail or private car the space, weight and cost of accommodating sporting equipment can be impactful. Sports facility providers, such as golf course managers, may alleviate these perceived inconveniences through improvements to the availability and quality of rental equipment (and promotion thereof). Within the golfing realm, there has been some move in this direction as companies offering for rent the latest brand equipment are established in popular golf holiday resorts. Furthermore the availability of rental equipment may open up new opportunities for those sports facility providers located adjacent to popular holiday centres to offer packages (for example, an inclusive golf package which provides transport to/from the course, hire of equipment, and green fee for entry to the course) which may stimulate participation from those sports enthusiasts who have travelled without equipment and who may perceive multiple impediments to playing while on vacation.

Furthermore travelling with sporting equipment (however limited in size) may act as a signifier of intentions which in and of itself may require significant negotiation with nonplayers within the travel group as to the expectations of the activities undertaken during the holiday. There is a symbolism associated with the sports equipment which can lead to negotiations around participation. This may stimulate a self-fulling prophecy of participation - that taking the equipment, on the off-chance that it might be used, will determine a negotiation justified by the assertion that equipment should be used having made the effort to transport it. More than a quarter of a century ago Bloch et al (1989) asserted that the role of the relationship between players and their equipment is worthy of further research and, while this paper has initiated some discussion of the topic, further examination of the impact that travelling with sporting equipment has on relationships is merited. 
Although this research has focused specifically on the influence that transporting golf equipment has for trip decision making, other sports which require specialist equipment of significant size or weight may also experience similar influences. Where equipment comes in multiple parts - in the case of shoes, gloves and balls for golf or, for example, scuba divers requiring air tanks, goggles, flippers and wetsuits to participate, so a combination of travelling with owned equipment and hiring equipment may occur. Yet this does not eliminate the influence that travelling with equipment has on the trip decision process nor the negotiations on participation which may shape decisions. Companies offering rental equipment will often need to provide the latest equipment to meet expectations of participants and this will come at an investment cost. Further research is needed in understanding the supply characteristics required for equipment rental companies to successfully divert amateur sports enthusiasts from travelling, often inconveniently, with their own equipment. 


\section{Bibliography}

ANABLE, J. 2006. Complacent Car Addicts or Aspiring Environmentalists? : Identifying Travel Behaviour Segments Using Attitude Theory. Transport Policy, 12, 65-78.

AUSTRALIAN GOLF INDUSTRY COUNCIL 2014. The value of golf tourism to Australia. Melbourne, Vic: AGIC.

BARRELL, G., CHAMBERLAIN, A., EVANS, J., HOLT, T. \& MACKEAN, J. 1989. Ideology and commitment in family life: A case study of runners. Leisure Studies, 8, 249-262.

BLOCH, P. H., BLACK, W. C. \& LICHTENSTEIN, D. 1989. Involvement with the equipment component of sport: Links to recreational commitment. Leisure Sciences, 11, 187200.

BOO, S., CARRUTHERS, C. P. \& BUSSER, J. A. 2014. The Constraints Experienced and Negotiation Strategies Attempted by Nonparticipants of a Festival Event. Journal of Travel \& Tourism Marketing, 31, 269-285.

BOYATZIS, R. E. 1998. Transforming qualitative information: thematic analysis and code development, London, Sage.

BREIVIK, G. 2011. Dangerous Play With the Elements: Towards a Phenomenology of Risk Sports. Sport, Ethics and Philosophy, 5, 314-330.

BRINGER, J. D., JOHNSTON, L. H. \& BRACKENRIDGE, C. H. 2006. Using Computer-Assisted Qualitative Data Analysis Software to Develop a Grounded Theory Project. Field Methods, 18, 245-266.

BUTLER, R. 2005. The influence of sport on destination development: the example of golf at St Andrews, Scotland. In: HIGHAM, J. (ed.) Sport tourism destinations. Oxford: Elsevier Butterworth-Heinemann.

CHARMAZ, K. 2006. Constructing grounded theory: a practical guide through qualitative analysis, London, Sage.

CHARMAZ, K. \& BRYANT, A. 2011. Grounded Theory and Credibility. In: SILVERMAN, D. (ed.) Qualitative Research. 3rd Edition ed. London: SAGE Publications.

CHOI, S., LEHTO, X. Y., MORRISON, A. M. \& JANG, S. 2011. Structure of Travel Planning Processes and Information Use Patterns. Journal of Travel Research.

COMPLETO, F. \& GUSTAVO, N. 2014. Golf Tourism Destination Management: Looking for a sustainable demand: The case of Portugal. Journal of Management and Sustainability, 4, 142-153.

CORREIA, A. \& PINTASSILGO, P. 2006. The golf players' motivations: The Algarve case. Tourism \& Hospitality Research, 6, 227-238.

CROMPTON, J. 1992. Structure of vacation destination choice sets. Annals of Tourism Research, 19, 420-434.

CROMPTON, J. L. \& ANKOMAH, P. K. 1993. Choice set propositions in destination decisions. Annals of Tourism Research, 20, 461-476.

CSIKSZENTMIHALYI, M. \& HALTON, E. 1981. The Meaning of Things: Domestic Symbols and the Self, Cambridge, Cambridge University Press.

DAENGBUPPHA, J., HEMMINGTON, N. \& WILKES, K. 2006. Using grounded theory to model visitor experiences at heritage sites: Methodological and practical issues. Qualitative Market Research: An International Journal, 9, 367-388.

DAVIS, H. L. 1976. Decision Making within the Household. Journal of Consumer Research, 2, 241-260.

DECROP, A. 2006. Vacation Decision Making, Wallingford, CABI. 
DECROP, A. \& SNELDERS, D. 2005. A grounded typology of vacation decision-making. Tourism Management, 26, 121-132.

DELLAERT, B. G. C., ETTEMA, D. F. \& LINDH, C. 1998. Multi-faceted tourist travel decisions: a constraint-based conceptual framework to describe tourists' sequential choices of travel components. Tourism Management, 19, 313-320.

DONNELLY, P. \& YOUNG, K. 2005. Rock Climbers and Rugby Players: Identity construction and confirmation. In: COAKLEY, J., COAKLEY, U. C. C. S. C. J. \& DONNELLY, P. (eds.) Inside Sports. London: Routledge.

FOURNIER, S. 1991. Meaning-based framework for the study of consumer-object relations. In: HOLMAN, R. H. \& SOLOMON, M. R. (eds.) Advances in Consumer Research. Provo, UT: Association for Consumer Research.

GAMMON, S. \& ROBINSON, T. 1997. Sport and tourism: a conceptual framework. Journal of Sport \& Tourism, 4, 11-18.

GEISSLER, G. L. 2005. An examination of the Golf vacation package-purchase decision: A case study in the US Gulf Coast Region. Journal of Hospitality and Leisure Marketing, 13, 65-82.

GILBERT, D. C. (ed.) 1991. An examination of the consumer behaviour process related to tourism, London: Belhaven Press.

GLASER, B. G. 1999. The Future of Grounded Theory. Qual Health Res, 9, 836-845.

GLASER, B. G. 2008. Conceptualization: On theory and theorizing using grounded theory. International Journal of Qualitative Methods, 1, 23-38.

GLASER, B. G. \& HOLTON, J. 2007. Remodeling Grounded Theory. Historical Social Research / Historische Sozialforschung. Supplement, 47-68.

GOFF, S. J., FICK, D. S. \& OPPLIGER, R. A. 1997. The moderating effect of spouse support on the relation between serious leisure and spouses' perceived leisure-family conflict. Journal of Leisure Research, 29, 47-60.

GOSLING, G. D. 2008. Airport Ground Access Mode Choice Models: A sythesis of airport practice. Washington D.C.: Transportation Research Board.

GROSS, S. \& KLEMMER, L. 2014. Introduction to Tourism Transport, Wallingford, CABI.

HARRY, B., STURGES, K. M. \& KLINGNER, J. K. 2005. Mapping the Process: An Exemplar of Process and Challenge in Grounded Theory Analysis. Educational Researcher, 34, 313.

HERGESELL, A. \& DICKINGER, A. 2013. Environmentally friendly holiday transport mode choices among students: the role of price, time and convenience. Journal of Sustainable Tourism, 24, 596-613.

HUDSON, S. \& HUDSON, L. 2014. Golf Tourism, Woodeaton, Oxford, Goodfellow Publishers.

HUMPHREYS, C. \& WEED, M. 2012. Golf Tourism and the Trip Decision Making Process: The Influence of Lifestage, Negotiation and Compromise, and the Existence of Tiered Decision Making Units. Leisure Studies.

HUTCHINSON, J., LAI, F. \& WANG, Y. 2009. Understanding the relationships of quality, value, equity, satisfaction, and behavioural intentions among golf travelers. Tourism Management, 30, 298-308.

HWANG, Y.-H., GRETZEL, U., XIANG, Z. \& FESENMAIER, D. R. 2006. Travel Destination Choice Models. In: FESENMAIER, D. R., WÖBER, K. W. \& WERTHNER, H. (eds.) Destination Recommendation Systems: Behavioral Foundations and Applications. Wallingford: CABI Pub. 
HYDE, K. F. 2004. A Duality in Vacation Decision Making. In: CROUCH, G. I., PERDUE, R. R., TIMMERMANS, H. J. P. \& UYSAL, M. (eds.) Consumer Psychology of Tourism, Hospitality and Leisure. Wallingford: CABI.

JORGE, J. P. \& MONTEIRO, C. 2011. Competitive choice dimensions of golf destinations: A multivariate perceptual mapping analysis. European Journal of Tourism, Hospitality and Recreation, 2, 29-54.

LAMONT, M., KENNELLY, M. \& MOYLE, B. 2014. Costs and Perseverance in Serious Leisure Careers. Leisure Sciences, 36, 144-160.

LAST, J. \& MANZ, W. Unselected mode alternatives: What drives modal choice in longdistance passenger transport? . 10th International Conference on Travel Behaviour Research, 10-15 August 2003 Lucerne.

MARKWICK, M. C. 2000. Golf tourism development, stakeholders, differing discourses and alternative agendas: the case of Malta. Tourism Management, 21, 515-524.

MCCABE, S., LI, C. \& CHEN, Z. 2015. Time for a Radical Reappraisal of Tourist Decision Making? Toward a New Conceptual Model. Journal of Travel Research.

MCGUIGGAN, R. L. 2004. A Model of Vacation Choice: an Integration of Personality and Vacation Choice with Leisure Constraints Theory. In: CROUCH, G. I., PERDUE, R. R., TIMMERMANS, H. J. P. \& UYSAL, M. (eds.) Consumer Psychology of Tourism, Hospitality and Leisure. Wallingford: CABI.

MILES, M. B. \& HUBERMAN, A. M. 1994. Qualitative data analysis: an expanded sourcebook, London, Sage.

MILL, R. C. \& MORRISON, A. M. 2012. The Tourism System, Kendall Hunt Publishing Company.

MINTEL 2014. Sports Participation - UK. London.

MINTEL 2015. Activity and Adventure Travel - UK. London.

ORTHNER, D. K. \& MANCINI, J. A. 1990. Leisure impacts on family interaction and cohesion. Journal of Leisure Research, 22, 125-137.

ORTUZAR, J. D. \& WILLUMSEN, L. G. 2011. Modelling Transport, Chichester, Wiley.

PETRICK, J. F. \& BACKMAN, S. J. 2002. An examination of the construct of perceived value for the prediction of golf travelers' intentions to revisit. Journal of Travel Research, $41,38-45$.

PRIDEAUX, B. 2000. The role of the transport system in destination development. Tourism Management, 21, 53-63.

RECKER, W. W., MCNALLY, M. G. \& ROOT, G. S. 1986. A model of complex travel behavior: Part I-Theoretical development. Transportation Research Part A: General, 20, 307318.

REED, P. G. \& RUNQUIST, J. J. 2007. Reformulation of a methodological concept in grounded theory. Nurs Sci Q, 20, 118-22.

ROBERTS, J., JONES, R., HARWOOD, C., MITCHELL, S. \& ROTHBERG, S. 2001. Human perceptions of sports equipment under playing conditions. Journal of Sports Sciences, 19, 485-497.

ROBINSON, T. \& GAMMON, S. 2004. A question of primary and secondary motives: revisiting and applying the sport tourism framework. Journal of Sport Tourism, 9, 221-233.

SAMSON, A. 2014. The Behavioural Economics Guide: (with a foreword by George Loewenstein and Rory Sutherland)

SCHMOLL, G. A. 1977. Tourism Promotion, London, Tourism International Press. 
SCOTTISH GOLF TOURISM 2013. Driving Forward Together: Scottish Golf Tourism Development Strategy 2013 - 2020. Scotland: Golf Tourism Development Group.

SHELDON, P. J. \& MAK, J. 1987. The Demand For Package Tours: A Mode Choice Model. Journal of Travel Research, 25, 13-17.

SILVERMAN, D. 2001. Interpreting qualitative data: methods for analysing talk, text and interaction, London, Sage.

SIRAKAYA, E. \& WOODSIDE, A. G. 2005. Building and testing theories of decision making by travellers. Tourism Management, 26, 815-832.

SKYSCANNER. 2014. Skyscanner's Simple Guide To Airlines' Ski Baggage Charges [Online]. Available: $\quad$ http://www.skyscanner.net/press-releases/skyscanners-simple-guideairlines-ski-baggage-charges [Accessed 10 November

SPORT ENGLAND 2014. Active People Interactive. In: ENGLAND, S. (ed.). London.

STARKS, H. \& BROWN TRINIDAD, S. 2007. Choose Your Method: A Comparison of Phenomenology, Discourse Analysis, and Grounded Theory. Qualitative Health Research, 17, 1372-1380.

STEBBINS, R. A. 1977. The Amateur: Two Sociological Definitions. The Pacific Sociological Review, 20, 582-606.

STONE, M. J. 2016. Deciding not to choose: Delegation to social surrogates in tourism decisions. Tourism Management, 57, 168-179.

STRAUSS, A. \& CORBIN, J. 1994. Grounded Theory Methodology: An overview. In: DENZIN, N. \& LINCOLN, Y. (eds.) Handbook of qualitative research. Thousand Oaks, CA: Sage.

STRAUSS, A. L. \& CORBIN, J. 1990. Basics of Qualitative Research: Grounded Theory Procedures and Techniques, London, Sage.

SWARBROOKE, J. \& HORNER, S. 1999. Consumer behaviour in tourism, Oxford, Butterworth Heinemann.

TASSIOPOULOS, D. \& HAYDAM, N. 2008. Golf tourists in South Africa: A demand-side study of a niche market in sports tourism. Tourism Management, 29, 870-882.

THORNTON, P. R., SHAW, G. \& WILLIAMS, A. M. 1997. Tourist group holiday decision-making and behaviour: the influence of children. Tourism Management, 18, 287-297.

TOURISM NEW ZEALAND 2013. New Zealand International Golf Tourism Strategy. Wellington: Tourism New Zealand,.

TOURISM NORTHERN IRELAND 2015. A Strategic Review of Golf Tourism in Northern Ireland 2015-2020. Belfast: Tourism Northern Ireland.

UM, S. \& CROMPTON, J. L. 1990. Attitude determinants in tourism destination choice. Annals of Tourism Research, 17, 432-448.

URQUHART, C. 2013. Grounded Theory for Qualitative Research: A Practical Guide, SAGE Publications.

USTEL, H. 2014. The Cost of Transporting your Bike by Plane [Online]. Available: https://totalwomenscycling.com/lifestyle/travel/cost-of-transporting-your-bike-byplane-27463/\#ZJR835wjbd2cmFuQ.97 [Accessed 11 June.

VAN METER, K. M. 1990. Methodological and Design Issues: Techniques for Assessing the Representatives of Snowball Samples. In: LAMBERT, E. Y. (ed.) Collection and Interpretation of Data From Hidden Populations. Rockville, MD: National Institute on Drug Abuse.

VAN RAAIJ, W. F. \& FRANCKEN, D. A. 1984. Vacation destincations, activities and satisfactions. Annals of Tourism Research, 11, 101-112. 
VAN SICKLE, G. 2016. A Club Rental Service That Saves Money and Hassle. Golf Magazine [Online]. Available: http://www.golf.com/equipment/club-rental-service-savesmoney-and-hassle [Accessed 26 February 2016].

WAHAB, S., CROMPTION, L. J. \& ROTHFIELD, L. M. 1976. Tourism Marketing, London, Tourism International Press.

WEED, M. \& BULL, C. 2012. Sports Tourism 2e: Participants, Policy and Providers, Taylor \& Francis.

WOODSIDE, A. G. \& LYSONSKI, S. 1989. A general model of traveller destination choice. Journal of Travel Research, 27, 8-14.

WOODSIDE, A. G. \& MACDONALD, R. 1994. General system framework of customer choice processes of tourism services

In: GASSER, R. V. \& WEIERMAIR, K. (eds.) Spoilt for choice. Decision-making processes and preference change of tourists Intertemporal and intercountry perspectives. Thaur, Germany: Kulturverlag.

YOUNG, B. W., DE JONG, G. C. \& MEDIC, N. 2015. Examining relationships between passion types, conflict and negative outcomes in masters athletes. International Journal of Sport and Exercise Psychology, 13, 132-149.

ZHANG, J., KUWANO, M., LEE, B. \& FUJIWARA, A. 2009. Modeling household discrete choice behavior incorporating heterogeneous group decision-making mechanisms. Transportation Research Part B: Methodological, 43, 230-250. 